\title{
The Postcoloniality of Poor African Leadership in Achebe's Fiction: A Close Reading of Arrow of God and $A$ Man of the People
}

\author{
Confidence Gbolo Sanka ${ }^{*}$, Patricia Gustafson-Asamoah ${ }^{1}$, Charity Azumi Issaka² \\ ${ }^{1}$ Department of English, Faculty of Social Sciences, Kwame Nkrumah University of Science And Technology, Kumasi, Ghana \\ ${ }^{2}$ Department of English, KNUST Senior High School, Kumasi, Ghana \\ Corresponding Author: Confidence Gbolo Sanka, E-mail: Fikoff75@Gmail.Com
}

\section{ARTICLE INFO}

Article history

Received: February 03, 2018

Accepted: April 20, 2018

Published: April 30, 2018

Volume: 6 Issue: 2

Conflicts of interest: None

Funding: None

\author{
Keywords: \\ Africa, \\ Poor Leadership, \\ Postcoloniality, \\ Power, \\ Responsibility, \\ Greed, \\ Corruption, \\ Social Tension,
}

\begin{abstract}
The paper aims at tracing the genesis of abuse of power and the irresponsibility that goes with it to its full blossoming in Achebe's fiction through a close reading of Arrow of God and A Man of the People. Disenchantment with leadership in Africa, especially after independence, is not new on the African literary scene. But to Achebe, the problems associated with poor leadership in Africa did not start after independence. Failure in leadership only worsened in most African countries after independence due to the perpetuation of colonial vestiges. By doing a close reading of the two novels and by using the theory of postcoloniality, the researchers compare the traditional world of Ezeulu in Arrow of God to the post-independence setting of Chief Nanga in A Man of the People. The paper concludes that Africa has gone beyond the politics of postcolonialism and is now at the postcoloniality stage. In order for Africans to truly overcome the perennial problem of poor leadership, there is the need for us to first accept our role as a continent in contributing towards the failure of leadership in Africa. There is also the urgency to encourage grass root participation and understanding of modern democracy, to build stronger institutions and to put in place heavier punishments for those who abuse power.
\end{abstract}

\section{INTRODUCTION}

The African novelist, both old and young, continue to engage their readers on the subject of poor leadership, abuse of power, corruption and their attendant effects on the African populace. Amu Djoleto(Money Galore), Chinua Achebe(Arrow of God, A Man of the People, Anthills of the Savannah), Ngugi Wa Thiongo (I Will Marry When I Want, Wizard of the Crow), Ayi Kwei Armah (The Beautyful Ones Are Not Yet Born, Osiris Rising), Okey Ndibe(Arrows of Rain) and Chimamanda Ngozie Adichie (Purple Hibiscus) are but a few of the writers who have touched on the subject in their writings. At the same time, development experts and critics such as Achebe (1983, 37-43), Egbue(2000), Uneke(2010), Idachaba(2014) and Oluwatayo(2018) continue to churn out mind boggling figures on the resources African people continually lose to corruption as a result of the abuse of power and the irresponsibility that goes with it. The exegesis on the effect of poor leadership on the living standard of the African and on the continent's economy are equally fascinating but worrying. All these indices only point to one thing: Africa has a leadership problem that must be addressed by Africans themselves.

Edward Said's seminal work, Orientalism: Western Representation of the Orient (1978) is believed to be the work that brought about post colonialism. Other critics such as Homi Bhabha, Spivak Gayatri and Ato Quayson later joined the criticism on post colonialism and presented various dimensions on the theory. Robert Young observes that the term postcolonial describes "the aftermath of the colonial" (13). He further notes that, "The situations and problems that have followed decolonisation ___ whether in the formerly colonising or colonised country are then encompassed in the term postcoloniality" (13). Young's explication of the term is in consonance with Ato Quayson's view on the meaning of postcoloniality. To him, the term refers to "a body of theory, a condition following liberation from a colonial power, or the processes whereby groups of people are thus liberated" (qtd in The Decolonised Librarian). Thus, African 
countries are not only living the conditions of decolonisation but they are also struggling to overcome these conditions in the era of neocolonialism. Ato Quayson's definition of postcoloinality is therefore apt for the discussion in this paper since we are discoursing the conditions of decolonisation in Nigeria and Africa and also proffering suggestions on how Africa can overcome the problem of poor leadership.

Indeed, Africa has gone beyond the politics of post colonialism and is now at the postcoloniality stage. For Africa to truly break the manacles of poor leadership and free itself from the ghost of colonialism, there is the need for us to first accept our role as a continent in contributing towards the failure of leadership in the continent. Grass root participation and understanding of modern democracy, stronger institutions which can generate proper regulatory and control mechanisms and harsher punishments for those who abuse power are all panacea to the problems of leadership in the continent.

Arguments in the paper have been presented by comparing the leadership style in traditional African society and that of the post-independence one; a discussion on the themes and narrative techniques of the two novels; a close reading of the narratives by concentrating on characterisation and the saturation technique of abuse of power and corruption before a conclusion is drawn.

\section{TRADITIONAL STYLE OF LEADERSHIP AND MODERN AFRICAN DEMOCRACY}

Traditionally, most African societies detest the concentration of absolute power in the hands of a few people. Even in societies where chiefs and kings are tolerated, the societies ensure that checks and balances in the form of strict moral and religious principles are put in place to avoid the misuse of power invested in the hands of the chief or the king. Besides these principles, councils of elders are also formed to help the kings and chiefs in the administration of power. In some cases, the society and the council of elders have the right to depose a chief or king when it is realised that such a leader is a disaster for the community. These qualities of responsibility and fairness in the use of power are reflected in Asar's definition of royalty in the traditional African setup in Armah's Osiris Rising: "Something halfway reasonable: a cooperative leadership chosen from founding families... It's the meeting that took the decisions" (169).

In the same vein, the Igbo society which Achebe writes about in Arrow of God is republican in nature. It believes in the inter-dependence between the individual and the society. In such a setup, no individual can win a battle against the clan or the society since the welfare of the community comes first. Consequently, they do not have the title of a king which may imply the concentration of much power in an individual's hand.

In modern democracy, particularly in Africa, things are different when it comes to who wields power in the society. Though the arms of government such as the legislature, the judiciary, and the executive are often put in place to check the excesses of one another, it often results in the situation where these arms of governments do not function independently. Consequently, they are not able to check the excesses of one another. Migai Akech is categorical in his paper when he states that abuse of power and corruption in Kenya, "is largely an institutional problem, rather than a cultural one" (343). This is the pitfall that Mbaku also refers to in his article when he observes that "The post-independence state in Africa not only failed to perform its protective functions well, but its structures were actually turned into instruments of plunder and exploitation in order to..."( 33 ).

What is surprising is that unlike the traditional context where there are moral and spiritual standards by which they judge the performance of their leaders, the situation is quite different when it comes to modern democracy in Africa. Many a time, it is the members of government who determine what is morally right for the society and not the other way round. In the African traditional setup, particularly in Ghana, there are several instances during which the ruled have successfully deposed or impeached a ruler for his failure to meet the values and standards required of him. On the other hand, many bad political leaders in Africa have only been overthrown through military coups because even under a democratic dispensation, such corrupt leaders would not make it possible for the ruled to impeach them. The military, in Africa, is also well known for its notoriety when it comes to abuse of power, corruption and irresponsibility (Adichie 205; Akingbe 1; Ndibe166-67; Ihonovbere 511; and Obeifuna 7) According to Egbue, in the absence of fear of penalty or sanctions, there is nothing to deter (those who wield power from) fraudulently enriching themselves"(86). This often results in the leaders abusing the power invested in them and going unpunished. Achebe attributes this to the failure of modern African leaders to "rise to the responsibility, to the challenge of personal example which are the hallmarks of true leadership" ("Where the Problem Lies" 1). This difference between traditional African leadership and Western democracy in Africa contributes significantly to the prevalence of abuse of authority and insensitivity in post-independence Africa. It also accounts for some of the prevailing social tensions in the form of armed conflicts, disagreement over election results, the scramble for the control of natural resources, and some of the chieftaincy disputes that have bedeviled us in Ghana.

\section{SYNOPSES, THEMES, AND NARRATIVE TECHNIQUES OF THE TWO NOVELS}

Arrow of God, though the third of Achebe's novels, comes next to Things Fall Apart in terms of the period which the setting of these novels refers to. They are both set in the early part of colonialism in Africa. Arrow of God tells the story of Ezeulu, the priest of Ulu. Ulu is the god that oversees the general welfare of the six villages of Umuaro. Ulu is created in reaction to the repeated defeats that the six villages of Umuaro suffered at the hands of the people of Abam. As the priest of the most powerful god of the six villages, Ezeulu wields a lot of authority. He controls the two most important seasons of planting and harvesting in the life of the six villages. Ezeulu, however, becomes so obsessed with power that he even forgets its source: the society. Consequently, 
when his detractors in the persons of Nwaka, Ezidemili and even Edogo start pointing out his mistakes to him and he also finds himself in trouble with the white government, Ezeulu decides to put his foot down and to establish his control over his people. Ezeulu does this in a very cynical way. He arrogates the power of Ulu to himself and is prepared to lead his people to destruction in order to get even with them for questioning some of his actions and decisions. The power of the people, however, reasserts itself. Ulu vindicates itself and exacts revenge on Ezeulu.

The messages in this narrative are almost consistent with those in Things Fall Apart. Thus, in the two novels, Achebe's concern of portraying the culture and history of his people is evident. Achebe's call for the exercise of power in a more restrained and responsible manner also exists in the two novels. The difference is that in Things Fall Apart, the theme of power and responsibility is subsumed whereas in Arrow of God, it is carved out as a major theme. This particular theme assumes more importance when one considers the fact that Ezeulu is chosen to serve as intermediary between his people and Ulu and nothing more.

To Achebe, there is no situation in which Ezeulu could have acted more responsibly than being the priest of Ulu. From the narrative, Ulu is created by the six villages of Umuaro so that it can protect them and they can also worship it. There is therefore a relationship of symbiosis between the god and its people. But in addition to this, Ezeulu is to serve his people as well as Ulu. It is his ability to juggle these two roles well that will indicate the extent to which he is responsible. Any abuse of the authority invested in him by his people can be disastrous just as the same misuse of the power invested in him by Ulu can be dangerous. It is this situation that calls for more restraint in Ezeulu's actions and decisions than any other character in the novel. As it turns out, Ezeulu is too arrogant and cannot accommodate dissenting views in the discharge of his duties.

As in many of his novels, Achebe uses a method of narration which revolves around allusions and implications. This method leaves much unsaid and brings about a lot of suggestiveness that tends to be more effective than explicit passages of narration. In short, he uses the Jamesian technique to "show" and not to "tell".

The other technique which Achebe uses in Arrow of God is foreshadowing. In many instances, references are made to certain aspects of Ezeulu's attitude and actions that point to his tendency to overreach himself. All these indicators precede the final chapters of the novel in which the true character and intentions of Ezeulu are unmasked and he is punished. The technique of foreshadowing therefore makes the structure of the novel a carefully planned one that creates and sustains suspense. The resolution is, however, anticlimactic in the sense that it raises questions about Ezeulu's credibility as a priest.

A Man of the People is also one of Achebe's political fictions that are set in post- independence Africa. The story takes place in a fictional African state with its capital as Bori. The story is equally narrated from the point of view of Odili. As the story opens, we are introduced to Chief M.A Nanga, who is painted in positive terms. He is not just the "most approachable politician in the country" but he is actually "a man of the people" (A Man of the People 1). It, however, takes a very close contact with Nanga in order to discover the other side of him. Odili's visit to the residence of the Nangas in Bori and his decision to contest Nanga for the same parliamentary seat provide opportunities for Odili to study Nanga and his cohorts closely. They are not just corrupt, intimidating, irresponsible, and greedy but they are also prepared to even kill in order to ensure they remain members of parliament forever. It is this abuse of power by Chief Nanga and the People's Organisation Party (P.O.P) which finally leads to the outbreak of the coup d'etat and the imprisonment of key members of the P.O.P.

Ironically, while Odili and Max detest and criticised the corrupt and repressive nature of the P.O.P government, they end up allowing themselves to be compromised by some elements of the P.O.P and other external forces. Odili, the narrator, even "borrows" some of the ill-acquired funds of their young party, Common People's Convention (C.P.C) in order to dowry Edna.

The main message of this novel has to do with power and the responsibility that goes with it. By highlighting issues such as corruption, nepotism, intimidation, or greed, Achebe aims at emphasising the theme of power and responsibility. It is the failure to administer power responsibly and to use it to serve the society that leads to the emergence of social tensions in the narrative. In a community where leadership is regarded as a means for enriching oneself and where power is seen as the prerogative of an individual and not of the society, one is likely to come across the misuse of such authority by the few individuals who wield it. Power, in such a context, becomes the absolute right of the one who exercises it and he decides what is good and what is morally wrong for the entire society.

In terms of narrative technique, Achebe uses a first- person narrator in the person of Odili. This, according to Bruce King, is significant since the first narrator is indicative of "the lack of traditional communal values in the new nation" (75). It is also clear that the novel is written in a satirical tone with a lot of irony and humour in it. Achebe cannot help but protest the wanton waste of the scarce resources in Africa by sycophants who parade themselves as politicians and by extension, the men of the people. This protest is subtly registered and even the narrator, Odili, is not aware that he forms the butt of Achebe's criticism. The irony and humour that accompany such a protest makes the story a very lively but clear sublimation of anger and indignation at the attitude and actions of the Nangas in Africa.

\section{ABUSE OF POWER AND IRRESPONSIBILITY IN THE TWO NOVELS}

According to Captain Winterbottom, Chief James Ikedi "was a complete nonentity until we crowned him" (Achebe, Arrow of God 107). But after Ikedi's appointment as Warrant Chief of Okperi, he turns himself into something else for his society. Ikedi has two character traits in him which do not befit a ruler in the Ibo traditional setup. First, Ikedi loves 
power and authority and is prepared to even create titles for himself in a society where they abhor such titles. To him, power does not belong to the people or the society but to the individual; and as such, a person in any privileged position can impose himself on his people through any means that he deems fit. It is this obsession with power in Ikedi that draws the following observation about him from Achebe in Arrow of God: "The latest thing he did was to get his people to make him an obi or king,... people who abominated kings" (Arrow of God 107).

The other attitude in Ikedi which does not make him a good ruler is his high-handedness and his corrupt nature. Ikedi is not only greedy but he also uses his authority without showing due concern for the consequences of his actions. The British Administration appoints him Warrant Chief and he goes to the extent of setting up a private court and an illegal prison by himself. He does not just feel content manipulating and torturing his own people in such an illegal court and prison but he is also convinced that every beautiful woman in the society belongs to him. He "marries" such women against their consent and he does not even think of performing the necessary marriage rites.

The systems of mass extortion that he organises among his kith and kin in order to enrich himself show his blatant disregard for their plight and his insatiable greed. These are qualities that can only make a bad leader out of Ikedi and cause his people to lose trust in him. The following observation made by Achebe regarding Ikedi's abuse of power and his corrupt attitude is worth noting: "Within three months of this man receiving his warrant Captain Winterbottom began to hear rumours of his high- handedness. He had setup an illegal court ..." (Arrow of God 58).

The involvement of the British Administration in the appointment of Ikedi as a Warrant Chief for Okperi does not mean that it is the source of Ikedi's high-handedness and his weak moral principles. His appointment as a Warrant Chief is only a catalyst for his irresponsible attitude. The fact is that the British Administration never appointed him king of his people. It is Ikedi's lust for power that pushes him to impose himself as a king on his people. Ikedi's decision to establish a private court and prison is an initiative taken by him alone. Besides, the fact that Winterbottom suspends Ikedi and subsequently withdraws his title goes a long way to illustrate that the British Administration does not support bad leaders like Ikedi in the context of this narrative. It is true that Ikedi is later on re-installed as Warrant Chief but this is a decision that is taken based on insufficient information and inexperience. Winterbottom himself admits that the "Senior Resident who had first come back from leave... had no firsthand knowledge of the matter..." (Achebe, Arrow of God 57).

It is, however, regrettable to note that some of the observations made by Winterbottom about the character of the African are sometimes not based on objective analysis. It is true that in the early period of colonialism, Africa had some individual rulers whose aim was not to unite their people but to create more divisions among them. Kofi Karikari in The Healers did nothing to unite the Akan family other than enslaving more Gold Coasters at his palace and sacrificing several others for ritual purposes. He did all these in an attempt to achieve his parochial interest. Kofi Karikari's attitude and that of Ikedi does not, however, reflect in the character of every African who finds himself in any privileged position as Winterbottom would want us to believe: "It's the same with Court Clerks and even messenger... It seems to be a trait in the character of the Negro" (Achebe, Arrow of God 57). As observed by Jenjekwa, African "indigenous knowledge systems do not condone corruption $(2016,188)$."

If the above observation coming from Winterbottom were true, then Africa would never have celebrated leaders and heroes like Nkrumah, Chaka, Toussaint, Mandela and so on. Again, if such a view were to hold water, there would never be any hope for Africa since we cannot talk of development when all we can offer is bad leadership which is inherent in our blood.

Ezeulu is the next character who symbolises abuse of power and irresponsibility in Arrow of God. As mentioned early on in this paper, Achebe uses foreshadowing to warn us against the intentions of Ezeulu as we begin to read the novel. The first sign of obsession with power that one finds in Ezeulu is his refusal to accept his human qualities. As an intermediary between Ulu and his people, Ezeulu is half man and half spirit. This is why during official ceremonies such as the Pumpkin Leaves Festival, the left half of his body is usually painted white. Most of the things which he says and does during such occasions originate from the gods. The only problem with this dual personality of Ezeulu is his refusal to acknowledge that he is human and must therefore accept all things that happen to all mortals. He feels that he is larger than life and that the normal vicissitudes of life which usually take their toll on all men resulting in old age or poor sight cannot affect him. Right from the first page of the narrative, readers are made aware that Ezeulu does not like the idea that he is growing old and as such, his sight and strength are negatively affected. He still wants to believe that his sight is as good as that of any young man and that he can still withstand the strength of any young man in Umuaro. He even feels that he is stronger than the young men and to prove this, he usually plays a particular game on them. "Whenever they shook hands with him he tensed his arm and put all his power into the grip, and being unprepared for it they winced and recoiled with pain" (Achebe, Arrow of God 107). Clearly, what Ezeulu does in this context is to deny his human qualities and to regard himself as a deity that cannot be affected by old age and its attendant effects.

The second method which Achebe uses to warn us against the shortfalls in the leadership style of Ezeulu at the very beginning of the novel is to help us gain an insight into Ezeulu's mind through the technique of stream of consciousness as he contemplates the immensity of his power on page three. In this particular instance, it is revealed through Ezeulu's thoughts that he is not just content with the control of the two most important seasons of harvesting and planting in the life of his people. He is not content with the power of a "watchman" or the power that a child exercises "over a goat that was said to be his" (Achebe, Arrow of God 1). The fact that no chief priest has ever refused to name the day for planting and harvesting does not please him too. In fact, all those limitations of his power are things that stung Ezeulu to 
anger "as though his enemy had spoken it" (Achebe, Arrow of God 3). To Ezeulu, his power as the priest of Ulu transcends all these barriers and he is convinced that "the woman who will bear the man who will say he dares not refuse to name a day for planting or harvesting has not yet been born" (Achebe, Arrow of God 3). In effect, Ezeulu understands his power to be limitless and that he can take it upon himself to name to or not to name the day for either of the two most important festivals of the people of Umuaro.

The last character trait of Ezeulu which Achebe uses to foreshadow his final usurpation of power from Ulu is his autocratic attitude. Ezeulu thinks that nobody must question his actions and decisions either within his family or in the community at large. This is what sometimes leads to the misunderstanding between Ezeulu and his children, wives or other members of the society. As Edogo's late mother puts it: "Ezeulu's only fault was that he expected everyone his wives, his kinsmen, his children, his friends and even his enemies to think and act like himself" (Achebe, Arrow of God 92). Oduche himself also observes that "he had never heard his father speak to any one as an equal" (Achebe, Arrow of God 45). This is another character trait which makes Ezeulu unable to accommodate other people's opinions and to even concede defeat to his fellow men when he has wronged them. He fails to admit that Oduche commits an abomination by locking up the royal python. The reality is that the intention of suffocating the reptile to death is clear from Oduche's action and this alone is an abomination. Ezeulu does not want to admit that he or his own child is capable of making a mistake.

Again, Ezeulu's stance against the people of Umuaro from waging war against Okperi over a piece of land does not stem from his love for truth or justice. His declaration that "Ulu" would not fight an unjust war is not based on any consultation with the oracle. He is simply against his own people either because he wants to protect the interest of his mother's village, which is Okperi, or he cannot accommodate any dissenting views.

Taking into account these character traits of Ezeulu which are delineated to the readers at the beginning of the narrative, we are not surprised when Ezeulu finally hatches a plan to punish his people for pointing out some of his mistakes to him. From his attitude and actions, we are made aware that Ezeulu is autocratic and intolerant of other people's opinions. Therefore, when Nwaka and the rest point it out to Ezeulu that Winterbottom is his friend and any summons from Winterbottom should not warrant a collective decision on whether to go or not, Ezeulu becomes satisfied. This is an instance in which he sets a trap for those he deems are stumbling blocks to his authoritative leadership. Fortunately for him, the people are not able to see through his tricks and they allow him to make the trip to Okepri all by himself. The point is that Ezeulu is looking for an excuse to punish Umuaro and the summons from Winterbottom provides a good opportunity.

Consequently, Ezeulu's refusal to eat the remaining tubers of yam and to name a day for the celebration of the New Yam Festival when he comes back from Okepri constitutes a clear abuse of office. A cursory look at the reasons advanced by Ezeulu and by the council of elders on this particular issue will help us uncover the true intentions of the Ulu priest.

Ezeulu refuses to eat the remaining tubers of yam at a go because, according to him, it is not customary for the Ulu priest to eat more than one tuber of yam at the beginning of every month. Apparently, he will be breaking custom if he does so. The fact that it is his detention at Okepri that leads to his inability to eat all the tubers of yam within the stipulated time seems to put him out of blame. A closer look at the role of the Ulu priest in the people's life and some of the authorial comments, however, seem to put all the blame at the feet of Ezeulu.

First, Ezeulu has ever travelled alone out of Umuaro to Okperi in order to give evidence against his own people when they had a dispute over a piece of land with the people of Okperi. He did so without consulting his people and he did not breach any custom. Therefore, his going to Okperi in order to respond to Winterbottom's summons is not the first and neither will it constitute an act that goes against the mores of Umuaro. Nwaka and his group are therefore right in pointing out to Ezeulu that it is not out of place for him alone to visit Winterbottom for a second time.

Also, it is evident from some of the authorial comments that Ezeulu's detention at Okperi is only a catalyst and not the original cause of his decision to usurp power from Ulu and use it to chastise the six villages of Umuaro. For instance, while Ezeulu is in detention at Okperi, the authorial comments give us an insight into Ezeulu's thoughts as follows: "But in spite of all this...The longer he was kept in Okperi the greater his grievance and his resources for the fight" (Achebe, Arrow of God 176).

This observation is important since it helps us to understand that Ezeulu's decision to punish Umuaro is pre-meditated and not accidental as he would want us to believe. Besides this point, Ulu has also warned Ezeulu against the idea of taking it upon himself to punish his people. It is the god's prerogative to decide when to punish Umuaro and what form the chastisement will take. This is why Ulu asks Ezeulu "who told you this was your own fight?"(Achebe, Arrow of God 191). Despite Ulu's warning, Ezeulu still goes ahead and initiates his plans to get even with his opponents. This implies that Ezeulu is simply arrogant and a despot and he is not ready to relent in his effort to torture his people even if it means annihilating the entire community.

Finally, the council of elders' visit to Ezeulu to persuade him to eat the rest of the yams and to name a day for the New Yam Festival is important since it exposes Ezeulu's thoughts on this issue. As Udeozo points out, ten elders represent Umuaro and its people and they have unanimously decided that Ezeulu should eat the yams. If Ezeulu did not have any ulterior motives, he would not have remained adamant even after the elders instructed him to eat the yams. After all, the god is witness to what the elders said. He should have eaten the yams and waited for the oracle to decide whether to punish Umuaro or not. Besides, Ulu as a god is created by the people of Umuaro to protect them so that they can also revere it. If at any point in time the people find out that Ulu's protection is no longer necessary, they can do away with it. 
There is no custom that is static and cannot be altered. This explains why Nnanyelugo gives several "examples of customs that had been altered in the past when they began to work hardship on the people" (Achebe, Arrow of God 209). Consequently, Ezeulu's argument that he cannot eat the yams simply because it is against the custom is baseless. Ezeulu also forgets that Igbo gods are not as unforgiving as he wants the council of elders to believe. This is why Nanyelugo again explains that in Igbo land, every offence against the gods "has its sacrifice from a few cowries to a cow or a human being" (Achebe, Arrow of God 209). Ulu could not have been offended to the extent that it is bent on destroying the entire population of Umuaro without asking for any pacification first. What Achebe does in Arrow of God is to tie up all the loose ends so that everything will point to Ezeulu as the one who is power drunk. He arrogates the powers of Ulu with the sole intention of seeking personal vendetta against his own people.

Ezeulu has no tangible excuse for his final decision which brings more hardship to the people of Umuaro. They are not simply denied their cultural right but they are made to wallow in misery and starvation in the midst of abundant food. It is this insensitive attitude of Ezeulu towards the plight of Umuaro that pushes Ulu to the wall and forces it to act in order to protect its image. If Ulu fails to act, the punishment that Ezeulu plans for his people will "afflict Umuaro like an ogulu-aro disease which counts a year and returns to its victim" (Achebe, Arrow of God 219). It will afflict Umuaro forever and Ulu itself would be blamed for irresponsibility.

In order to prevent the visitation of such punishment upon its people and to protect its image, Ulu decides to destory itself. When it was created, a human being was offered to it in order to give it potency. It is therefore appropriate that for it to destory itself, another human being has to be sacrificed and Ulu chooses no other person than the son of Ezeulu. What even pains Ezeulu the more is that on the day of his son's death, he loses the favour of Ulu. Therefore, there was "no next time for Ezeulu" (Achebe, Arrow of God 228). The events in the narrative are patterned in such a way that they make it possible for Achebe to drive home his final message. Ezeulu is not merely an arrow in the bow of Ulu as he wants Umuaro to believe. He tries to be the shooter of the bow of Ulu and this is why the oracle teaches him that "no man however great can win judgement against his people" (Achebe, Arrow of God 131).

In fact, the eating of the twelve tubers of yam in a year by Ezeulu is symoblic in many ways. Apart from the fact that nobody eats such yams except the priest of Ulu, one must also recognise the repubican nature of the principle governing the eating of such yams. They are not to be taken according to the personal discreton of the priest. They are eaten at the beginning of every month so as to accomplish an important task of the Ulu priest and to help the entire society to keep track of the counting of the months. Ezeulu is quite aware that he cannot refuse to eat the symbolic tubers of yams unless otherwise decreed by the god itself or by Umuaro as a whole. He, Ezeulu, cannot usurp the power of Ulu unless he is prepared to face the consequences.

In $A$ Woman in Her Prime by Alex Konadu, the celebra- tion of the Odwira festival is dependent on the accurate calculations of three priests who are assigned three different bags to drop a grain of corn into them each day. At the end of the year, each of the three priests is supposed to have three hundred and fifty grains in his bag. A mistake in the calculation from any of the three priests will not be tolerated and the least punishment that is given such a priest is to is to depose him. As Pokuwaa's mother observes, "no self-respecting priest would cause an announcement to be made unless he is sure it is one month to the festival" since such a priest could risk his life, and that of his sons and daughters if custom is to be taken to the utmost". (58) This indicates that in African traiditional setups, the priest is simply an interpreter of the will of his people and their gods and that he cannot usurp powers that do not belong to him.

In A Man of the People, it is Chief Nanga who epitomizes abuse of authority and irresponsibility and their sequel effect of corruption. Some of the characters are guilty of the same weakness but to a lesser degree. The first example of abuse of office and recklessness that we find in Nanga's personality is his intimidating attitude. Both Nanga and Koko will stop at nothing; from bribery through intimidation of the village people to physical assault and battery to get what they want. As Neal Ascherson notes in his review of Anthills of the Savannah:

During the years of open political contest, the first "independence" generation recklessly allowed the distinction between power and force to be blurred, until those whose trade was force began in increasing numbers to drive their tanks across that line. (3)

The attitude of Nanga and his cohorts as well as Ascherson's observation go a long way to confirm Raymond Tuvi's view in his article entitled Leadership: A Call to Serve. In the July 14, 2008 edition of the Daily Graphic, Tuvi observes that:

Unfortunately, due to motives other than the interest of the group to be led, leadership in the human world today can be bought and sold, and it could also be attained through violence. Sadly, this is the situation prevailing in many scenarios around the world. (23)

To Nanga and his group, the issues of tolerance and fair play which are always preached by the ancients among contestants do not apply to politics. Odili's father expresses the need for tolerance between Nanga and Odili through the Igbo proverb that "I believe that the hawk should perch and the eagle perch, whichever says to the other don't may its wing break" (Achebe, A Man of the People 122). Chief Nanga's repressive moves to ensure that he retains his seat in parliament and consequently his ministerial position is an example of the problem with many contemporary African leaders: "On top of that he has brought you two hundred and fifty pounds if you will sign this paper... Projected Rural Water Scheme" (Achebe, A Man of the People 132, 146-9).

Nanga and his group do not only use their authority to intimidate people so as to get what they want from them but they are also against any form of opposition. As Achebe writes, both Odili and Chief Nanga himself are aware that the latter will retain his seat in the impending elections with or without Odili's oppostion. Chief Nanga himself confirms 
that he is bound to win the elections when he tells Odili "I am not afraid of you. Every goat and every fowl in this country... disgrace yourself" (Achebe, A Man of the People 118) .In spite of this assured knowledge, Chief Nanga is not willing to tolerate any opposition at all, perferring to be elected unopposed since that will increase his prestige in the capital and will also be an indication of the people's trust in him. "I am only giving you this money ... behind me" (Achebe, A Man of the People 40-41). Chief Koko even decides to be more ruthless by refusing to bribe his opponents but to kill some in a very heartless manner.

The prevalence of corruption in the society is a natural sequel of abuse of power and irresponsibilty on the part of Nanga and his cohorts. Corruption is common in the fictional African state largely because politicians like Nanga, Koko and the rest have decided to use their good offices to embezzle state funds to the detriment of the development of the entire nation. In a country where the state cannot even afford to provide decent public toilets for its citizens and they rather have to use pails for excrement, some few people, like Nanga, continue to live in " the cosy comfort of a princely seven bathroom mansion with its gleaming..."(Achebe, A Man of the People 54). It is estimated by the "African Union that corruption costs in African economies are more than 148 billion American dollars anually" (Uneke 112) and it has also been established in Africa that "the constrainsts to broadbased economic growth have been traced to corruption, debt relief and donor aids, insecurity and other negative externalities in Africa" (Oluwatayo 60).

The Minister for Constuction does not waste time lining his pocket and putting up mansions in order to let them out to embassies. He behaves like Koomson in The Beautyful Ones Are Not Yet Born who succeeds in buying fleets of fishing boats through fraudulent means. As Jean points it out to Odili, "that row of the ten houses belongs to the Minister of Construction... three thousand a year each"(Achebe, A Man of the People 34). In both past and present Africa, political leaders have always managed to embezzle funds and stash them away in their foreign accounts. Sometimes, the monies stolen cannot be recovered after such leaders are dead and gone since the monies are kept in fictitious and secret accounts. Moboutou Sesseko, Sani Abacha, Umar Bongo, and a host of others have caused their respective countries severe financial hemorrhage by plundering state funds and stashing them in foreign bank accounts.

The leader of the P.O.P. who is the Prime Minister does not also hesitate in misusing his authority in order to perpetuate his stay in government. He does not waste time in sacking the Minister of Finance when the latter suggests a reduction in prices paid to coffee farmers in order to cope with the slump in coffee price at the world market. Instead, the Prime Minister orders that new currency up to the tune of fifteen million pounds be printed. He does not want to pay less to farmers so as to lose the forthcoming elections. Even if it means creating artificial inflation in order to get elected; or sacking the Minister of Finance and two-thirds of the cabinet single-handedly, the Prime Minister is prepared to do just that. In Ghana and other African states, during an electioneering year, economic gains made after elections are always eroded by "expansionary fiscal and/or monetary stimuli to forster economic growth and, with it, maximize the probality of re-election" (Chiripanhura and Nino-Zarazua 1389). This usually draws the country back to economic doldrums. The political leaders are well aware of this, but the desire of incumbency is always so alluring that they are prepared to gamble the economic gains made for political power. In the context of the narrative, the Prime Minister can count on the support of the Nangas and Kokos who Odili describes as a pack of "hounds" and "hungry hyenas" fighting for juicy political appointments. Indeed, Odili describes the political situation in his country as follows: "We had all been in the rain together until yesterday. Then a handfull of us - the smart and the lucky and hardly ever the... house" (Achebe, A Man of the People 37).

All these illustrations on the misuse of power, irresponsibility and their natural sequel of corruption have serious "politial, economic, social and environmental implications" for the country and the citizens" (Idachaba, 2014). and Achebe successfully uses the saturation technique in presenting them in the two narratives. Besides, the lack of conscience for the results of the actions of the Nangas and Kokos leads them to commit serious crimes by engaging in intimidation, assualt, battery, plunder, and even murder. It is thus the insensitivity of the political leaders that plunges the whole nation into a state of chaos at the end of the novel.

Beyond the abuse of office and the insensitivity that goes with it, one must admit that other factors also contribute to the general disorder which characterises the city of Bori and other parts of the country. One of such factors which is personal greed has already been discussed in the form of corruption. The motivating factor behind graft in the context of the narrative is personal greed. It cannot be argued that the Nangas and the Kokos are corrupt simply because they are not well paid by the government. Apparently, they are treated better than they deserve but personal greed will push them to amass wealth for themselves.

As pointed out earlier, the difference between the use of power in African traditional setups and in modern democracy in Africa is the absence of a moral and ethical monitoring system for the leaders and citizens. It is the lack of standards by which leaders in post-independence Africa could be assessed by their own people that makes the abuse of power, irresponsibility and corruption in the new era more prevalent. For example, the Ikedis, Nangas and Kokos wield absolute power over their people and the citizens remain powerless since it is the same oppresors who control the laws, the press, the legislature and so on. In contrast, leadership in the traditional context is tied up with the mores of the people. In this setup, it is the people__ the living, the dead, the gods, spirits___ who determine how they should be ruled. Ezeulu has to allow the decision of the people to prevail since he turns out to be a false priest. Even if the living cannot enforce their will, the spirits and gods will help them do it. In such a society, even the outcasts are given much protection and any evil act against them is discouraged completely. Josiah loses his business because the people at the village where traditional values are still respected will not tolerate the method he chooses to enrich himself. It 
is against the culture of the people in the traditional context. The fact that he calls the blind man into his shop under the pretext of feeding him only to steal his walking stick for ritual purposes is unacceptable. On the other hand, the Ikedis and Nangas who belong to different periods but are representatives of western democracy even extort monies from people and kill others in order to enrich themselves and still get away with it.

It is this same point that Bruce King develops when he sums up the difference between responsibility in the traditional context as in Arrow of God and responsibility in the new nation as in the $A$ Man of the People as follows:

Whether the clan is right or wrong _ and it is often wrong it has its special mechanisms of reconciliation, judgement, sanctions and survival; the new nation state produced by colonialism, as seen in No Longer at Ease and $A$ Man of the People, has no organic unity, no moral sense, no mechanism of purgation, its values follow from the corrupting powers given the warrant chiefs, messengers and police by the colonial government.(King 75)

African society's apathy and cynicism towards modern democracy is another factor that encourages abuse of office and recklessness among political leaders. Thus, in the first place, African societies usually expect the politician to be rich and generous like Nanga. He should be able to bring not just development to his village, town or constituency but he should also be able to help individuals in the society with their financial problems. The politician must distritute money like Mour Ndiaye does it to the beggars in The Beggars Strike when the politician attends rallies and other meetings organised in his honour. It is society's expectations of the politicians that sometimes push them to engage in financial malfeasance. The people of Urua even feel that it is better for them to vote for Odili not because he is more competent than Nanga but because they will also get their share of the national cake if he is elected. In short, while the society seems to condone corruption by engaging in nepotism, by expecting the politician to be rich and to solve all the financial problems of individual members of the society for them, it is the same society that cries foul when it finds out that the political leaders are embezzling their taxes.

It is not just the society's cynicism that Achebe finds as a factor hampering good governance in Africa but the grass root's lack of understanding and apathy towards modern democracy in Africa. There is a distance between modern democracy and traditional societies in Africa. Individuals in the traditional societies, especially the non-literate ones often think that the new form of governance is imported and it is not their government even if their sons are now in control of affairs. It is their understanding that the government belongs to only those who can read and write and not all the citizens of the country. Consequently, they do not express any concern about the way they are governed. They lack an understanding of the power they have when it comes to modern democracy. They will not readily sanction a political leader for abuse of power the way they will easily sanction a traditional leader for the same offence. When Edna's mother learnt that Odili is contesting Chief
Nanga's seat "she listened carefully, thought about it and then said...What do we know?" (Achebe, A Man of the People 119). It is this lack of understanding and participation in governance by the masses which Igue bemoans when he observes that "So since 1960 the State has never been adopted by the Africans. The State is the product of foreign powers and represents the passing of the baton of ...the dominant powers" (2010).

\section{CONCLUSION}

From the discussion of the various issues in this paper, Achebe's approach to the question of leadership in Africa is clear and logical. He does not simply start his criticism based on the performance of post-independence African governments. He goes back to the period preceding Africa's contact with Europe and assesses the performance of African leadership from then up to date. He does not blame the white man for all the problems in Africa. To Achebe, Africans played and still play a critical role in shaping the destiny of our continent. It is this role assigned Africans that should be examined from its historical perspective to the present. It must be admitted that, to some extent, Africa had some bad leaders like Ezeulu in the past, and that Africa needs stronger institutions and not demi-gods. African leaders and societies have a role in setting a moral and ethical monitoring system for leadership and in encouraging grass root participation and understanding of modern democracy. The continent cannot continue to blame Europe for all our leadership predicaments and this is how we can actually deal with abuse of office and insensitivity among our leaders. Africa is not a lost cause and there is nothing wrong with the character of the Negro. Achebe summarizes the task confronting Nigeria and her sister African countries in terms of leadership as follows:

The trouble with Nigeria is simply and squarely a failure of leadership. There is nothing basically wrong with the Nigeria land or character or water or air or anything else. The Nigeria problem is the unwillingness or inability of its leaders to rise to the responsibility, to the challenge of personal example which are the hallmarks of leadership.(1)

\section{REFERENCES}

Achebe, Chinua.(1988) A Man of the People, Oxford: Heinemann Educational Publishers, pp. 149.

Achebe, Chinua.(1986) Arrow of God, Oxford: Heinemann Educational Publishers, pp. 230.

Achebe, Chinua.(1984) Problem Lies" The Trouble with Nigeria, Oxford: Heinemann Educational Books, pp. 1-3.

Adichie, Ngozi Chimamanda. (2006) Purple Hibiscus. Lagos: Farafina, 336.

Akech, Migai, (2011) "Abuse of Power and Corruption in Kenya: Will the New Constitution Enhance Government Accountability?" Idiana Journal of Global Studies, 18(1), pp. 341-394.

Akingbe, Niyi.(2010). "Saints and Sinners: Protest in Wainting for an Angel." The Journal of Interntional Social 
Research. 3(11), pp. 27-32.

Armah, Ayi Kwei.(1995) Osiris Rising, Popenguine: PER ANKH, pp. 305.

Ascherson, N.(1988), "Betrayal", Review of Anthills of the Savannah by Chinua Achebe, The New York Review of Books.

Chiripanhura, B and Miguel N.(2015). "Aid, Political Business Cycles and Growth in Africa. Journal of International Development, 27, pp.1387-1421.

Egbue, N. G. (2006). “Africa: Cultural Dimensions of Corruption and Possibilities for Change" Journal of Social Science, 12(2), pp. 83-91.

Idachaba, F. S. (2014) "Government Corruption and the Underdeveloped Nigerian Agriculture.”, a lecture delivered at the Prof. Samson Olayide Memorial Lecture, University of Ibadan, Nigeria, 20 ${ }^{\text {th }}$ March 2014, pp. 15-25.

Ihonvbere, O. Julius. (1998) "The Military and the Nigerian Society." The Military and Militarism in Africa. Dakar: CODESRIA.

Igue, John O.(2010) "A New Generation of Leaders in Africa: What Issues Do They Face?", International Development Policy, translated by Sarah Jordan, Geneva: Graduate Institute, 1/2010, 115-133.

Jenjekwa, Vincent.(2016) "Locating Indiginous Knowledge Systems: Discourse on Corruption in Zimbabwe." Africology: The Journal of Pan African Studies, 9(1), pp.188-201.

King, Bruce.(1980) The New English Lieratures, ed. Profes- sor A. N. Jeffares, London: The Macmillan Press Limited. Konadu, Asare, 2002, A Woman in Her Prime,: Adaex Educational Publication Limited, Accra, pp. 139.

Mbaku, John M., (2000). "Governance, Wealth Creation, and Development in Africa: The Challenges and the Prospects", African Studies Quarterly, 4(2), pp. 29-46.

Ndibe, Okey. (2000) Arrows of Rain. London: Heinemann, pp. 248.

Obeifuna, Philip Ojimadu. (1994) "How the Military Wrecked Nigeria." in Tell, Februay 14, 1994.

Oluwatayo, Isaac B. (2018) "Walking through a Tightrope: The Challenge of Economic Growth and Poverty in Africa." The Journal of Developing Areas 52(1), pp. 59-69.

TheDecolonized Librarian(2013)“Postcoloniality/ies."https:// decolonizedlibrarian.wordpress.com/2013/12/16/postcolonialities. [Last accessed on 2018 July 01].

Tuvi, Raymond.(2008), "Leadership: A Call to Serve”, Daily Graphic, Accra: Graphic Communications Group Limited, pp. 23 .

Uneke O. (2010) "Africa South of the Sahara: Bureaucratic Facilitator or Handicap to Development?" The Journal of Pan African Studies 3(6), pp. 111-128.

Young, RJC(2009). "What Is Postcoloniality?" https:// journalhosting.ucalgary.ca/index.php/article/download/33560/27604. [Last accessed on 2018 July 01]. 